\title{
Correction to: A Phase I Study to Evaluate the Pharmacokinetics and Safety of Lorlatinib in Adults with Mild, Moderate, and Severe Renal Impairment
}

\author{
Swan Lin ${ }^{1}$ (1) Jason Gong ${ }^{2} \cdot$ George C. Canas $^{3} \cdot$ Peter Winkle $^{4} \cdot$ Kathleen Pelletier $^{5} \cdot$ Robert R. LaBadie $^{5}$. \\ Katherine Ginman ${ }^{5}$. Yazdi K. Pithavala ${ }^{1}$
}

Published online: 8 March 2022

(c) The Author(s) 2022

\section{Correction to: European Journal of Drug Metabolism and Pharmacokinetics \\ https://doi.org/10.1007/s13318-021-00747-4}

Unfortunately, the correction in Fig. 2 was not updated in the online published article. The figure correction is now updated.

The original article has been corrected.
Open Access This article is licensed under a Creative Commons Attribution-NonCommercial 4.0 International License, which permits any non-commercial use, sharing, adaptation, distribution and reproduction in any medium or format, as long as you give appropriate credit to the original author(s) and the source, provide a link to the Creative Commons licence, and indicate if changes were made. The images or other third party material in this article are included in the article's Creative Commons licence, unless indicated otherwise in a credit line to the material. If material is not included in the article's Creative Commons licence and your intended use is not permitted by statutory regulation or exceeds the permitted use, you will need to obtain permission directly from the copyright holder. To view a copy of this licence, visit http://creativecommons.org/licenses/by-nc/4.0/.

The original article can be found online at https://doi.org/10.1007/ s13318-021-00747-4.

Swan Lin

swandlin@gmail.com

1 Pfizer Inc., Global Product Development, San Diego, CA, USA

2 Pfizer Inc., Global Product Development, New York, NY, USA

3 Prism Research Inc., Prism Clinical Research, St. Paul, MN, USA

4 Anaheim Clinical Trials, Orange, CA, USA

5 Pfizer Inc., Global Product Development, Groton, CT, USA 